\title{
Economic Contributions and Challenges of Immigrant Entrepreneurs to Their Host Country - Case of African Immigrants in Auckland, New Zealand
}

\author{
Olufemi Muibi Omisakin ${ }^{1}$ \\ ${ }^{1}$ Nelson Marlborough Institute of Technology, Global Campus, 42 Upper Queen Street, Eden Terrace, Auckland \\ 1010 New Zealand \\ Correspondence: Olufemi Muibi Omisakin, Nelson Marlborough Institute of Technology, Global Campus, 42 Upper \\ Queen Street, Eden Terrace, Auckland 1010 New Zealand
}

Received: February 15, 2017

Accepted: March 9, 2017

Online Published: March 13, 2017

doi:10.5430/jbar.v6n1p25

URL: https://doi.org/10.5430/jbar.v6n1p25

\begin{abstract}
Entrepreneurship is an important concept in both developing and developed societies today. Although there is no consensus on the definition of entrepreneurship, it is believed to be a process of creating value by bringing together a unique package of resources to exploit entrepreneurship opportunities (Morris, 2002). This study aims to discover the economic contributions and challenges of immigrant entrepreneurs to their host country, and focuses on African small business owners in Auckland, New Zealand. Literature on immigrant entrepreneurship was reviewed, resulting in a discussion of the economic contributions of immigrant entrepreneurship as well as its challenges. Data was collected using face-to-face, semi-structured interviews, observation and field notes as the sources of inquiry. A purposive sampling technique was used to select 17 participants. All participants were African immigrant small business owners running businesses in Auckland. Thematic analysis was used to analyse the data collected (Braun \& Clarke, 2006).
\end{abstract}

Keywords: African immigrants, African entrepreneurs, Entrepreneurship, Entrepreneurship Challenges, Immigrant entrepreneurship - Auckland, New Zealand

\section{Rationale of the Study}

An overview of immigrant entrepreneurship literature shows that there has been little focus on African entrepreneurial activities within the context of the economic contribution and associated challenges in Auckland, New Zealand. Therefore, this identified gap is the focus of this study. The study is carried out in Auckland because it houses three-quarters of African immigrants in New Zealand, as well as their business activities.

\section{Introduction}

New Zealand is a small nation with a population of 4.5 million in 2016 (Statistics New Zealand, 2016) and therefore it has a relatively small domestic market. The backbone of the New Zealand economy is its small and medium enterprises [SMEs] which are piloted by entrepreneurs (Omisakin, Nakhid, Littrell, \& Verbitsky, 2015). New Zealand SMEs constitute up to $90.7 \%$ of all firms and provide about $50 \%$ of New Zealanders with jobs (Omisakin et al., 2015). Because of the size of its population, New Zealand is committed to promoting the export of its domestic production to foreign markets. Therefore, New Zealand has signed both bi-lateral and multi-lateral trade agreements, including a common economic relationship with Australia in 1983, the New Zealand-China trade agreement in 2008, and the most recently signed multinational trade agreement, called Trans Pacific Partnership Agreement (TPPA). It is argued in international business that domestic businesses with access to international markets can attain more rapid growth and long-term profitability, leading to overall economic growth and development (Charles, 2015). For this and other reasons, New Zealand's choice to encourage its export markets in the face of its population challenge is most welcome.

Globally, entrepreneurship is an important concept in both developing and developed societies today. There has been a growing interest by researchers investigating entrepreneurial activities and, as a result, entrepreneurship has become a popular construct but with various meanings. Today, in the academic world, there is no consensus on the definition of entrepreneurship; hence, many researchers adopt their own definitions of entrepreneurship and create 
their own terms within the area of their study. Entrepreneurship is regarded as the creation of wealth, enterprise, innovation, change, employment, value, and the creation of growth, among other things (Morris, Kuratko, \& Covin, 2008). Morris (2002) concluded that entrepreneurship is the process of creating value by bringing together a unique package of resources to exploit an opportunity.

Apart from migrating because of natural phenomena such as earthquakes, tsunami and other natural disasters, people also migrate for economic, political and social factors. Most individuals would prefer to live where there are limited natural disasters and where there is economic prosperity, there are political rights, freedom, and where the government is socially responsible. However, when these are seriously lacking, people will seek to migrate. This explains why Africans and people from the Middle East make up a higher percentage of migrants. New Zealand has been a popular destination for migrants, but until recently there has not been much African migration to New Zealand; this could be associated with the distance. The adoption of a formal refugee quota by New Zealand in 1987 opened up opportunities for Africans from war-torn countries to migrate to New Zealand as refugees in the early 90s.

The study adopted the interpretive paradigm using semi-structured interviews to collect data from 17 participants purposively selected from among African small business owners in Auckland. Two theories (cultural theory and opportunity structure theory) were used to explore immigrant entrepreneurs' contributions and the phenomenon of immigrants' entrepreneur challenges. Findings from this study show that immigrants have been contributing to the New Zealand economy by creating employment for people, creating new businesses, serving as a connecting pipe between New Zealand domestic businesses and international businesses, and contributing to the economic growth and development through payment of various taxes. However, immigrant businesses are faced with numerous challenges, among which are the inability to secure finance, high taxes compared with their level of business, a small population, utility bills, competition and high costs of running businesses. This study is structured into eight chapters: chapter 1, introduction; chapter 2, literature review; chapter 3, theories (theoretical perspectives); chapter 4, research methodology; chapter 5, presentation of findings and discussion; chapter 6 , recommendations; chapter 7 , suggestions for further research; chapter 8 , conclusion.

\subsection{Objectives of the Study}

This study sets out to examine the economic contributions and challenges of African immigrants who are small business owners in Auckland, New Zealand. Specifically, the objectives set out for this study include:

- To examine the African immigrants' entrepreneurial contributions to their host country's economic growth and development;

- To investigate the challenges African entrepreneurs face in their involvement in business activities.

\subsection{Research Question}

The study aims to answer the two following questions:

- What are the economic contributions of African immigrants to the growth and development of New Zealand's economy?

- What are the challenges encountered by African immigrants involved in small business activities in Auckland?

\subsection{Limitation of the Study}

According to Baltimore County Public Schools (2015), researchers carrying out studies are expected to highlight and explain the limitations they may have faced in their act of carrying out their studies. The researcher of this study encountered the following limitations on the study:

- Limiting the study to Auckland, New Zealand, constitutes a limitation to the study. However, Auckland was selected because it is the largest city in New Zealand with a population of 1,415,550 [33.4\%] (Gomez, King \& Jackson, 2014). Auckland also houses about $50 \%$ of the African population in New Zealand. The African population of New Zealand is 13,464, and 6,306 reside in Auckland (New Zealand Statistics, 2013).

- Sample size of 17 appears to be small; the study intended to have 20 participants but the interviews had to be stopped at the $17^{\text {th }}$ participant when we got to saturation point.

- The participants of the study were mainly from indigenous African ethnic groups, therefore, it might not be seen as a good representation of the wider multi-ethnicity of New Zealand. However, adequate recommendations are made to mitigate these limitations. 


\section{Literature Review}

\subsection{Concept of Entrepreneurship}

The word 'entrepreneur' is French and is literally translated as 'between-taker' or 'go-between' (Hisrich \& Peters, 2002a). Looking at the term 'entrepreneur' from the perspective of economic literature, Cantillon (1734) introduced it as a risk taker. Entrepreneurs are regarded as extraordinary people with a great ability to utilise other factors of production to produce goods needed by mankind. Entrepreneurs are therefore regarded as active figures in the business world and its processes, and essential to grow and develop the economy of most countries.

Generally, an entrepreneur is seen as the person who bears the risk of coordinating all other factors of production and who possesses the psychological capacity to energise and coordinate entrepreneurial activities. There are a number of characteristics and traits that an entrepreneur must possess to enhance a business: an entrepreneur must be innovative, be able to take at least a minimum risk, be autonomous, be able to persevere, have some level of independence, and have an internal locus of control (Aggarwal \& Gupta, 2006; Hisrich \& Peters, 2002b; Morris, 2002). However, immigrant studies have reacted against this, saying that looking only at the individual qualities and abilities of entrepreneurs does not make an entrepreneur. According to Lumpkin and Dess (1996), other factors beyond the entrepreneur's control and ability can also predict entrepreneurial success. Therefore, Lumpkin and Dess argue that entrepreneurship is the interaction between the individual and opportunities in the environment. It can be concluded that entrepreneurship can be seen as the ability of the entrepreneur to identify and exploit opportunities within an environment that are previously unidentified and unexploited. From the above, entrepreneurship involves multiple events such as recognition of an opportunity and acting on the identified opportunity.

Though the term entrepreneurship has been used for decades, still there is no consensus about its definition and the processes involved (Williams, Round, \& Rodgers, 2010). In an attempt to give a concise definition to entrepreneurship, Morris, Kuratko, and Covin (2008) summarised the common themes found in entrepreneurship literature as the creation of wealth, enterprise, innovation, change, employment, value and growth. However, Morris et al. ended up describing entrepreneurship as a process of creating value by bringing together a unique package of resources to exploit an opportunity.

Entrepreneurship studies have suggested several factors needed to attain entrepreneurial success. Such factors include culture, age, education, gender, managerial know-how, industry experience, social skills, entrepreneurial readiness, length of time, size of enterprise, and capital (Charney \& Libercap, 2000; Kolveried, 1996; Kristiansen, Furuholt, \& Wahid, 2003; Mazzarol, Volery, Doss, \& Thein, 1999). It is also argued that cultural perspective, which affects firms' performance, could influence entrepreneurial activities. Entrepreneurship studies have corroborated the opinions of the researchers in this area (Lee \& Peterson, 2000; Mueller \& Thomas, 2001). Some entrepreneurship studies have suggested that entrepreneurs aged between 25 and 44 years are the most entrepreneurially active (Kristiansen et al., 2003) and that the male gender is more into entrepreneurship and more helpful in entrepreneurial intention than females (Charney \& Libercap, 2000; Kolveried, 1996; Mazzarol et al., 1999), and they concluded that education produces self-sufficient entrepreneurs.

Many of these factors are relevant to entrepreneurship, but an entrepreneur also needs to possess some personality traits that ensure business success. Forbes (2015) identified five personality traits that ensure an entrepreneur will succeed in business. These factors are:

Passion: It is most important that an entrepreneur should have passion for business to be successful. Without passion, it might be difficult for an entrepreneur to get beyond the initial level. Being passionate goes beyond monetary value. Resilience: Being an entrepreneur is challenging, especially financially, but entrepreneurs should be able to learn from past challenges and come back from failure. Self-awareness: A successful entrepreneur should be able to identify his/her strengths and weaknesses and use these to better his/her business. Patience: To be successful in business an entrepreneur must have patience in dealing with employee relationships, business negotiations and communications, so that the business goal can be attained. Persistence: An entrepreneur must be persistent; starting a business requires persistence because in reality reaping benefits takes longer than expected.

Another factor shown to influence entrepreneur business success is family background (Glancey, Greig, \& Pettigrew, 1998). It is also said that entrepreneurial readiness is a reference to entrepreneurs' self-efficacy to succeed and attain business goals, leading to business success (Cromie, 2000). Self-efficacy is a foundation of human motivation and personal accomplishment. Kristiansen and Indarti (2004) found a significant correlation between self-efficacy and entrepreneurial intention. 


\subsection{Contribution and Significance of Immigrant Entrepreneurs to Host Countries}

Immigrants are globally perceived as being highly skilful, entrepreneurial and are needed for economic growth, development and innovation. McEvoy and Barratt (1992) analysed migrants' business motivation and identified pull and push factors. Domboka (2013) found Black African women were motivated into business in the UK by various pull factors: the discovery of a business opportunity, financial gain, wanting to be their own boss; and push factors: inability to secure a good job; being discriminated against in the labour market. Schmis (2013) found Vietnamese in Germany were self-employed because of their inability to secure jobs in the restricted German labour market. Similar studies carried out in New Zealand found that immigrants in New Zealand were discriminated against while searching for a job, leading some to becoming self-employed (Butcher, Spoonley, \& Trlin, 2006). However, some immigrants are pulled into entrepreneurship because they want to be their own boss and need extra income.

Irrespective of immigrants' motivation, the contributions of immigrant entrepreneurs are visible in most countries and they are mostly essential in most developed and developing economies for this reason and others. Most developed and developing countries have created special visas and entry requirements in an attempt to attract immigrant entrepreneurs (Fairlie. \& Lofstrom, 2013). Similarly, Immigration New Zealand follows the same pattern of these countries to attract skilled immigrants and immigrant entrepreneurs to help propel the New Zealand economy. According to Immigration New Zealand (2016), a potential immigrant qualifies for a three-year entrepreneur work visa if he/she can secure a minimum capital investment of NZ $\$ 100,000$ with a clear business plan, clean history of no bankruptcy, business failure and fraud, has good health and character, and meets the English language requirement.

It has been confirmed by entrepreneurship authors that creating business is higher among the foreign-born than the native-born in countries such as the United States, United Kingdom, Canada and Australia (Borjas, 1994; Clark \& Drinkwater, 2000; Fairlie, 2008; Lofstrom, 2002). According to Fairlie and Lofstrom (2013), immigrant entrepreneurs are making substantial contributions in the technology and engineering sectors of the economy in the US. Above all, immigrant entrepreneurs have been spectacular in giving employment to both immigrant and local workers, thereby reducing social tension that could have resulted from a high rate of unemployment. Immigrant entrepreneurs' contribution to their host countries is not only noticeable in cities, but also in villages and rural areas.

According to Dana (1995), immigrant entrepreneurs made an immense contribution to the economic growth and development of the remote sub-Arctic community by being the chief source of jobs. Immigrants, with their entrepreneurial activities and skills, contribute to the growth of their host country both in the cities and suburbs by increasing the quantity and quality of goods and services produced, thereby making available various good and services (Kloosterman \& Rath, 2003). Entrepreneurship is seen as a source of economic growth and, if properly managed, it should serve as a source of national prosperity.

Entrepreneurship studies identify countries such as the United States, Canada, the United Kingdom and Australia as the main destination for immigrants. They are believed to be more prosperous and developed because immigrant entrepreneurs play a prominent role in their economic development by injecting new capital into the economy, establishing new businesses and, more importantly, creating employment leading to wealth creation. From previous studies, the same is applicable to New Zealand. Immigrants have injected new capital into the New Zealand economy, established new businesses, and provided employment for both migrants and locals, making New Zealand society better off (Hunter, 2007; Masurel. et al., 2004).

According to Whitehead, Purdy and Mascarenhas-Keyes (2003), ethnic minority businesses (EM) in the UK account for $9.8 \%$ of small businesses with employees. The Greater London Authority (2005) assessed the contribution of Asian-owned small businesses in London and highlighted the following: most Asian-owned firms are relatively small and 56\% have one to four employees; some migrant Asians (Chinese) are more likely to be self-employed.

\subsection{Challenges of Immigrants in Business Activities}

Migrants' challenging experiences can be analysed from two perspectives: before and after migrating. Sometimes migrants migrate when they can no longer cope with the challenging situation in their home country (due to political, economic and social adversity). This explains why migrants from North Africa are willing to cross the Mediterranean Sea to Europe against all odds to establish a new life (Nkrumah., 2003). This also explains why migrants sail in boats from Sri Lanka to Australia across the Indian Ocean. On arrival in their host country, migrants are faced with the challenging experience of settlement, culture, language, employment and a host of other factors. The most important challenge for a migrant to overcome is finding employment, as this is fundamental to being able to sustain himself/herself. However, gaining employment is not easy as migrants are often discriminated against for a number 
of reasons, including being unable to speak the host country language fluently, or from a lack of host country work experience. Mostly, migrants go into small businesses because of the challenging experiences they have had in the labour market or because they recognise an opportunity to run a particular business (Volery, 2007b). Borjas (1986) asserted that migrants can more easily secure employment or start running small businesses within their ethnic enclave. Borjas' view was that as more migrants of the same ethnic nationality begin to live in the same enclave, various business opportunities will spring up in response to the needs of the group.

Immigrants start their businesses amidst challenges and anticipate challenges as they start to run the business, though they might not know the extent of the challenges they will encounter. Irrespective of the immigrants' host country, the most common challenge for immigrants in business is finance. Financial challenges could come at the start of the business, while it is running or when it is needed for expansion. Reasons could include the formal financial sector not being willing to make funds available to immigrant businesses because they are sceptical of the immigrant businesses' ability to pay it back. For instance, Ram and Deakins (1996) found that African-Caribbean immigrants in small businesses in the UK were faced with finance problems and it was evident that banks were biased against assisting them. This group of immigrant business owners succeeded because they were self-motivated and optimistic about their businesses. Similarly Robb and Fairlie (2007) argued that immigrant businesses are less likely to have loans approved and are therefore less likely to apply for loans because of fear of denial, and are also more reluctant to initiate loans for their business ventures. Contrary to this, Kollinger and Minniti (2006) pointed out that if immigrant business owners have what is valued enough to be collateral, it might not be difficult for such businesses to secure loans from a financial institution.

According to Brenner, Ramangalahy, Filion, Menzies, and Amit (2000), Chinese entrepreneurs in Canada are faced with challenges associated with access to finance, marketing/sales, management skills, high tax rates and a low level of business survival. Similarly Holguin, Gamboa, and Hoy (2007) found Hispanic small business owners in the US are faced with problems of raising capital either at start-up or for future growth because they are often unable to obtain loans from the financial markets. While the most common challenge among immigrant entrepreneurs is finance, some immigrant entrepreneurs' challenges go beyond this. According to Fawcett and Gardner (2006), after comparing challenges faced by both Korean and Filipino entrepreneurs in the US, the authors found that Koreans are faced with the problem of a lack of proficiency in English.

Immigrant small business entrepreneurs in Australia are challenged by their inability to familiarise themselves with how businesses should be run in Australia, and a lack of cultural awareness of their new environment (Collins, 2003). Corroborating this, Gaskill et al. (1993) argued that small immigrant businesses in Australia face four major challenges for survival: poor strategic management, poor marketing, a competitive environment, and the difficulties of growth. The authors concluded that unless these four challenges are well handled by the manager/owner, the business will fail.

Pinkowski (1998) observed that immigrant small business owners in the UK, Germany, the US and the Netherlands are faced with seven challenges when carrying on their business. These challenges are:

- How immigrant small business owners will acquire the information that they need to establish a business and survive,

- How immigrant small business owners will acquire the capital necessary to fund a business,

- Where immigrant small business owners will get training and acquire the skills necessary to run a small business enterprise,

- How to recruit and manage an honest, competent and affordable workforce,

- How to manage customer and supplier relationships, especially with different languages or business practice models,

- How to survive serious competition in the new environment,

- How immigrant small business owners protect themselves and their co-ethnics from political attacks.

Pinkowski (2009) found that due to immigrants' cultural backgrounds or previous homeland experiences, they are generally not willing to seek assistance from government-run centres as they do not trust them. 


\section{Theories}

\subsection{Theoretical Perspective}

Several theoretical paradigms are relevant to the investigation of immigrants' business opportunities. The most prominent are opportunity structure theory (Aldrich \& Waldinger, 1990; Volery, 2007a), middleman minority theory (Blalock, 1967; Bonacich, 1993), ethnic enclave theory (Lee, 2003; Wilson \& Portes, 1980), labour disadvantage theory (Baycan-Levent., Gulumser, Kundak, Nijkamp, \& Sahin, 2006; Volery, 2007b) and cultural theory (Hofstede, 1997; Masurel.., Nijkamp, \& Vindigni., 2004; Volery, 2007b). A review of the literature indicates that these theories have been employed in research explorations of immigrant businesses for a number of years (Aldrich \& Waldinger, 1990; Lee, 2003; Masurel.. et al., 2004; Volery, 2007b; Zhou, 2004).

This study adopted cultural theory and opportunity structure theory to explore the phenomenon of African immigrants' challenges before business start-up and while running a small business in Auckland. The researcher reviews the use of these theories in resolving participants' challenges in running businesses.

Hoftstede (2011, p. 3) defined culture as "a collective programming of the mind which distinguishes the member of one group or category of people from another". Culture is regarded as a collective phenomenon that is shaped by an individual's social environment. Scholars of migration have emphasised cultural values like hard work, involvement of family members, religious ties and trust as the main source of some immigrant cultural groups' successes in business (Bonacich, 1973; Waldinger et al., 1990). The researcher agreed with the author as these factors helped most participants in the study to keep their businesses alive during times of difficulty.

According to the cultural theory, ethnic cultural resources assist immigrants in their business start-ups and the growth of their businesses in their host country. Most participants in the study used ethnic resources to grow, as a customer base, and to finance their businesses. For instance, almost all participants lack finance from the formal sector. The only source open to them was the ethnic community. This could be by networking for finance through their ethnicity or nationality. Participants also culturally sourced funds for their businesses through families and friends. Apart from these, most immigrants' businesses, particularly those dealing in culturally related businesses, depended on their ethnic group for customers and business growth. Participants who deal in African foods, clothing/fashion obviously will depend on customers of African ethnicity for their business. That is why they mostly complained of low population or size of market as one of the challenges of their businesses.

The cultural perspective also suggests that immigrants who relocate to their host country with entrepreneurial skills and abilities previously developed in their home country, a pre-migration cultural tradition of entrepreneurial mentality, great knowledge of an ethnic social network, and with an ethnic niche market, will be successful in their immigrant entrepreneurial performance (Chrysostome \& Arcand, 2009). This also explains why some participants in this study claimed that their type of business (African fashion, hair, barbing) was mostly learnt through their involvement in African culture before migrating to New Zealand.

According to Aldrich and Waldinger (1990), migrant opportunity structure is made up of "market conditions, access to ownership, job market conditions, and legal and institutional frameworks". Opportunity structures may be available through which migrant entrepreneurs can access business opportunities. Findings from this study identify with Aldrich and Waldinger's opportunity structures. Two participants, who were struggling and willing to establish their businesses in a particular sector and region, were able to do this when the situation permitted. One participant was able to penetrate a white-dominated business because the owner of the business she bought was relocating to Australia and no other buyer was available. Similarly, a second participant bought a business not common among Africans when other bidders were not forthcoming because they could not raise the funds. Other participants had the opportunity to own businesses when the first and second generation of children of the owners were not interested in continuing with the business. Opportunity structures created an opportunity for these African immigrant entrepreneurs to access these businesses when the existing local business owner was relocating, or there was no willingness from family members to continue with the business. This opportunity enables a migrant business owner to open his business in a non-African ethnic immigrant market. Aldrich \& Waldinger (1990) suggested that at retirement, it is likely that first-generation immigrants sell off their businesses (because their first- and second-generation children are not willing to take up generational businesses), therefore, newly arrived migrants looking for businesses could grab these opportunities and buy a business.

In this study, participants belonging to the same cultural and ethnic community, which helped generate the required resources for their business take-off, created co-ethnic feeling, relationships and interactions. This further helps generate business finance, business information, training, and the necessary market needed by their businesses. 


\section{Research Methodology}

\subsection{Method of Data Collection}

This study employed an interpretive case study research approach for its data collection. Case study research examines a phenomenon using one or more methods of data collection such as interviews, documentary reviews, archival records, direct observation, participant observation and field notes (Yin, 1994).

Myers (2008) argues that case study research in business-related studies uses empirical evidence from the group or organisation studied in an attempt to research the subject matter in context. (Myers, 2009). Interview methods were mainly used for data collection. A document review plays a crucial role in case study research because it forms a rich source of evidence to complement interviews. Documents can take the form of letters, internal memos, reports, newspaper articles and so on. Some participants provided their power bills, rent bills, and water bills to support their argument that it is expensive to run businesses in Auckland.

Businesses recommended through snowball sampling techniques were visited covertly to negotiate inclusion in the study. The visit involved direct observation of each business. This gave the researcher an opportunity to assess whether the recommended business met the study's participant selection criteria, which emphasised that the owner must be an African migrant, and the business must be of African value. The researcher obtained more information to augment other information sources such as field notes and interviews.

Field notes of the visits to business premises were made to identify the location, age group and ethnic backgrounds of owners, as well as the number of staff employed and customer profiles. The researcher compared the field notes taken during visits to notes taken during and after the main interview. This enabled the researcher to build a rich description of each participating business.

\subsection{Interviews}

The most preferred technique for interpretive studies is the interview technique because it is regarded as the most effective in accessing and interpreting information collected from the participants (Myers \& Newman, 2007). By interviewing participants, they were able to voice their challenges as well as what they have been contributing to the New Zealand economy. (Bryman, 2008). To attain the desired goal of this study, the interviewer made use of semi-structured interviews.

\subsection{Semi-structured Interviews}

A semi-structured interview is a qualitative method of inquiry with the use of predetermined sets of open-ended questions by the interviewer that are meant to extract opinions, information and ideas from the participants about the topic at hand (Saunders et al., 2009). The researcher designs a semi-structured, open-ended, interview question schedule about the contributions and challenges for participants in running businesses. Questions were meant to extract immigrant business contributions to the New Zealand economy and their challenges (Bryman, 2009). I ensured I wrote observation notes while the interviews were on, which gave me an opportunity to record in writing my observations about the interviews, especially any non-verbal communication by participants that cannot be recorded on tape (Denscombe., 1998). I also probed the interviewees further on their responses to the questions where necessary.

It was difficult for the researcher to estimate accurately the number of African migrant businesses or entrepreneurs in Auckland because there has been no data in this regard by government or its agencies. In this type of scenario, the researcher can employ a purposive method in the selection of participants (Grinnell \& Unrau, 2005). In qualitative data collection, purposive sampling can "hand-pick" a sample for the study, but selecting or hand-picking must reflect the quality of experience and knowledge with relevance to the research problems (Denscombe., 1998). Therefore, purposive sampling was used for this study because it allowed the selection of participants on the basis of the participants' knowledge of the research problem (Grinnell \& Unrau, 2005).

The proposed study sample comprises 15-20 participants who are African migrant small business entrepreneurs in Auckland. However, the researcher stopped further interviews when there was an indication that the interviews had attained saturation.

In this study, the initial approach to known networks was explored. For example, access to some migrant community associations was secured. Such associations as the African Communities Forum Inc. (ACOFI) Auckland, Association of Nigerians in New Zealand, Ghanaian Association of New Zealand, Ethiopian Community of Auckland and the Zimbabwean Association of New Zealand approved the researcher's visits to association meetings where the 
research was advertised and participants solicited. These initial contacts then introduced the researcher and the research to members who were willing to participate in the research interviews.

\subsection{Data Analysis}

Data in this study took the form of interview transcripts collected from research participants that reflected on African immigrant entrepreneur economic contributions to New Zealand as well as the challenges in running businesses. Thematic analysis was used to analyse data collected. Thematic analysis is defined as a process of identifying, analysing and organising themes from the data collected. To establish this, the researcher carefully read and re-read the data collected (Rice \& Ezzy, 1999). Anderson Anderson (2007) regarded thematic analysis as the most foundational of qualitative analytic procedures because of its informed objectivity. Using thematic analysis enabled the researcher to obtain themes to describe the phenomenon under study (Daly, Kellehear, \& Gliksman, 1997).

\section{Presentation of Findings and Discussion}

Findings from this study will be discussed, starting with the participants' information and their business characteristics.

\section{Participants' Information}

The study found that four participants started their businesses five years before the study; three participants commenced their business four years earlier; four participants had been involved in business activities for three, seven, 18 and 20 years respectively; two participants revealed that their businesses had been running for the past 10 and four years. However, four participants had only started their businesses a year before the study.

\section{Participants by Age}

The participants were between 30 and 58 years old. Six participants were male and 11 were female. The reason for the wide gap between the males and females involved in business activities, as observed by the researcher, was that females are more likely to start small business because of the need to help upgrade the family income, work closer to home to care for children, and, from a cultural perspective, most African females learn the art and skills of African traditional businesses from their mothers. The 11 females in this study are in the beauty industry and African food sector of the economy.

\section{Participants by Years in New Zealand}

Four participants had been in New Zealand for between five and nine years. Seven participants had been in New Zealand between 10 and 14 years while five had been in New Zealand for between 15 and 20 years and only one participant had been in New Zealand for more than 20 years. More than two-thirds of participants had been in New Zealand for more than 10 years.

\subsection{Economic Contribution of Immigrant Entrepreneurs}

The most important contribution made by African immigrant entrepreneurs to the New Zealand economy is in creating wealth and employment by establishing new businesses and growing businesses in New Zealand, and increasing the country's global linkages. Creating businesses enables African immigrant entrepreneurs to provide employment opportunities for other immigrants as well as locals. All participants in this study employed between two and six employees. Employees were from different ethnic groups in Auckland, New Zealand. Related literature argues that migrant businesses are found in all sectors of business and economic activities in most developed and developing countries, contributing to economic growth (Fairlie, 2008; Fairlie \& Lofstrom, 2013). These businesses provide employment for both migrants and locals making New Zealand society better off (Hunter, 2007; Masurel. et al., 2004).

African entrepreneurs are contributing to the New Zealand global business network. They bring trade and investment opportunities and grow New Zealand business. One of the participant is the sole importer of Dark and Lovely, which she brought to New Zealand 19 years ago, and she has also brought other products to New Zealand. Another participant is the sole importer of two African foods from Australia. Other participants import and export products. Migrants' personal networks have contributed greatly to the New Zealand economy by attracting foreign investment and promoting trade with other countries (Morgan, 2002).

The study indicated that participants were contributing their quota to the development and growth of the New Zealand economy through payment of business taxes, collecting goods and services tax (gst) from customers on behalf of the government, and remitting these to the appropriate government departments. Participants generate income for their employees and government through taxes paid by their employees. This is helping the New Zealand 
economy to grow and develop, and resolve some associated social problems. Participants in the study who engage in import and export of goods and services generate import and export duties and other port-related charges for the government. Most of the businesses represent a link (intermediary) between New Zealand and other countries. However, while some businesses had been running for five to 15 years making profits and contributions to the economy, some had not been making progress, and the New Zealand government should assist them, as recommended in the study.

Findings in this study were similar to the results of some other entrepreneurship research; for instance, Mamani (2016) found immigrants contributed to Canadian prosperity because they mostly owned small business and incorporated more businesses than the locals. Similar to New Zealand, 24\% of SMEs in Canada with at least one employee are owned by immigrants (Statistic Canada 2014). Okonta and Pandya (2007) confirmed the entrepreneurial capabilities and the positive economic contributions of African and Afro-Caribbean immigrants in the United Kingdom. Similarly Ram and Deakins (1996) acknowledged the roles of African minorities using their networks to facilitate businesses to and from African countries to the UK.

Most participants in the study consider themselves as ambassadors of African culture. They are proud of their culture, and promotion of their cultural heritage in New Zealand was their priority. They started by introducing many new African foods and fashions to New Zealand, including distinctively African hairstyles such as African braiding, weavings and dreadlocks. Today, African fashions, cuisine and culture are part of the multicultural offerings in New Zealand. Every year, a day is dedicated to Africans in Parliament in Wellington. African churches and mosques are attended by non-Africans, there is an African day and festival in Auckland. African migrants are socially responsible in New Zealand society (Walrond., 2012), and African migrants work in all facets of New Zealand organisations such as the corrections department, NZ Customs Service, the police force, hospitals, colleges and universities. African migrants have made New Zealand a multicultural society and have contributed greatly to New Zealand being a tolerant society that reflects the wider diversity of values of the rest of the world.

It is a common difficulty for African immigrant entrepreneurs to secure loans from financial institutions at the start of their businesses. As a result they mobilise funds from their home countries, friends, family, ethnic connections, and personal savings, injecting new capital into the New Zealand economy. Apart from this, the average African immigrant possesses great value and skills in entrepreneurship, entrepreneurial orientation and education; today's immigrant children also contribute to the future labour force. Another important contribution of African entrepreneurs to the New Zealand economy is in revitalising dying businesses. Two participants bought one dying business each, injected fresh capital into them, and today the businesses are doing fine.

Table 1. Challenges in running business

\begin{tabular}{lc}
\hline Challenges & $\begin{array}{c}\text { Number of } \\
\text { participants }\end{array}$ \\
\hline High cost of running business & 5 \\
Lower population/customer & 5 \\
Difficult to run business & 5 \\
Customer inability to pay for goods bought or & 2 \\
services rendered & \\
Total & 17 \\
\hline
\end{tabular}

The above table shows the types of challenges immigrant entrepreneurs face in running businesses in Auckland, New Zealand.

\subsection{Identified Challenges}

The study found that immigrant business owners in Auckland are mostly confronted with challenges such as the high cost of running businesses, low population leading to low sales, difficulties in running businesses, and customer inability to pay for services rendered.

\subsubsection{High cost of Running Businesses}

Five participants experienced high costs in running their businesses in Auckland. The high costs were incurred through high power bills, high rents and high taxes. It is challenging because their businesses are small and, with continual increases in utility bills and without increased sales volumes, they are bound to run at a loss. Participants were of the view that income from their businesses was not sufficient to pay for business bills. They claim that 
sometimes they needed loans to pay off bills owed. Two participants claimed that in the past they had sold their valuables to offset bills.

\subsubsection{Lower Population/Customer}

Five participants relate their challenging experiences of running business in New Zealand to population. They all agreed that the size of a country's population plays a big role in the level of sales leading to profit. Their argument was from two perspectives: the number of African immigrants in New Zealand is very low, which has a negative effect on their businesses, particularly for those involved in African goods; those who deal in universal business also view the size of New Zealand's population as being relatively small compared with its land size and history. According to Volery (2007b), one factor that makes businesses profitable is population, which is important for business growth because, without customers, a business will die a natural death. However, the opinions of the participants were that the New Zealand government needs to grow the population. This might be right from their perspective of making profit when there is a huge population. However, it goes beyond that as more population requires more infrastructure which costs money and takes time. The researcher believes that the greatest resources any country has are people, because without people all other resources are useless. Therefore, I am of the opinion that New Zealand needs to grow its population subject to available resources. On the other side, participants running at a loss could collaborate with a view to reducing their losses.

\subsubsection{Difficult to Run A Business}

It was hard and challenging for five participants to start up, as well as run their businesses after take-off. Some explained that it was like a war for them at start-up, because of their inability to meet with some requirements, and after take-off of the business, especially their inability to source finance from the financial sector. However, the researcher observed that one contributory reason for participants' challenges in running businesses was that some of them lacked knowledge of running businesses and they did not have prior knowledge of New Zealand customers' buying attitudes and behaviours. In fairness to these participants, some were pushed into starting businesses, therefore, they may have a shallow knowledge of entrepreneurship. This is justified by the data collected from participants, which shows some did not have a sound knowledge of the art of business in their host country.

\subsubsection{Customer Inability to Pay for Services Rendered}

The study found that when some participants were dealing with their African customers, they found that some of them did not have money to spend because they were refugees and depended on support from the government. Some who had jobs complained that the pay was never enough, while some had been searching for a job without success. For this reason, they were unable to purchase used items that welfare offered to them at low prices, much less buy new items. This has negative effects on other African businesses as well, because some who are expected to patronise these businesses lack resources to do so.

Some challenges faced by participants in this study are similar to those found by Pinkowski (1998) in his study of immigrant small business owners in the UK, Germany and the US. The author summarised his finding as follows: immigrants are challenged in the acquisition of capital necessary to start up businesses; immigrants lack information needed to establish businesses; immigrant small businesses often lack the capability to survive in highly competitive environments. Similarly, Schmis (2013) identified that minority business owners often experience financial challenges in running businesses in their host countries. According to Holguin, Gamboa, and Hoy (2007), Hispanic small business owners in the US are challenged in raising capital to start businesses. These challenges, as identified by this author, may lead businesses into hardship and the costs of running businesses might go up, as found in this study.

However, this study is unique in two findings: businesses are challenged by low population/market/customers; the inability of customers to pay for services rendered to them. The researcher categorises this as the study's contribution to entrepreneurship literature and study.

\section{Recommendations}

The recommendations below are possible approaches to dealing with the challenges of African immigrant entrepreneurs running businesses in New Zealand.

The study recommends New Zealand grows its population by allowing more migrants (skilled and migrants with entrepreneurial orientation). With more population the country will be able to produce more consumables for people to purchase. With this, New Zealand will not be dependent on other countries for consumables, and business will flow because businesses flourish when there is population to buy what is produced. Julian Simon, in his lecture 
covered by C-SPAN.org, Mar 27, 1997 entitled Material Welfare and Standard of Living, said "the ultimate resource of any country is people" (skilled, energetic, innovative, hopeful young people with economic and business endowments) (Simon, 1997). In conclusion, New Zealand should not leave its economic fate in the hand of other countries.

From my personal contact with participants, it became obvious that most of them lack the knowledge and ability to prepare simple budgeting, bookkeeping and financial statements. Therefore, this study recommends that the African community requires a kind of "African business advisory board" that would help African entrepreneurs in these areas of need: business budgeting, business finance, bookkeeping and preparation of financial statements for businesses.

The study recommends that government should establish specialised financial institutions like a small business development bank, a national industrial bank such as in Canada (Business Development Bank of Canada), also in Nigeria (Nigeria Industrial Development Bank). Such banks if established should be made accessible to small businesses being run by immigrants, who could be given loans to start or run their businesses at cheaper rates compared to banking and/or other financial institutions.

\section{Suggestions for Further Research}

It is recommended that another study, not limited to one ethnic group, be carried out on the entire business sector in Auckland, New Zealand, to find out if the same motivational factors induced them into business. The outcome of such a study will reveal if the motivational factor is the same for the entire population of small business entrepreneurs in Auckland or if there are differences.

Another area of future research could be that we have only 17 participants in this study. This is a small sample size and the results cannot be generalised to all immigrant business owners in Auckland. Therefore, further research could be done by taking a larger sample which could produce more relevant results that can be more general.

\section{Conclusion}

The purpose of this study was to examine the economic contributions and challenges of immigrant entrepreneurs. The study focused on African immigrant entrepreneurs in Auckland, New Zealand. The aim of this study was to produce a previously unavailable document on indigenous African migrants' involvement in business activities in Auckland, New Zealand.

The researcher concludes this study from the findings of Anetomang (2009) that small businesses play an important role in employment creation, poverty reduction, innovation, diversification and in the growth of the economies of nations.

Generally, small businesses play a crucial role in the development of every country, be it developing or developed. For this reason, many countries have enabled the growth of the small business industry by creating opportunities for its establishment. This is mostly aimed at job creation and the contribution towards the growth of national and local economies.

Participants in this study created employment through their business activities for a large number of people, provided tax revenue for the government, improved the standard of living of people, and contributed to the development of the country. While the study found the contributions of participants as discussed above, it also acknowledged the following challenges participants faced in their involvement in business activities: high costs of running businesses; low population; difficulty in running businesses, customers' inability to pay for goods bought and/or services rendered. The study also discussed how the cultural and opportunity structure could help immigrants alleviate their business challenges.

However, while the findings of this study are mostly similar to previous academic findings, the following are observed as being unique to this study: low population; customers' inability to pay for goods bought and/or services rendered. The researcher considers this as the study's contribution to entrepreneurship literature and bridging the gap in literature in this area.

The study made appropriate recommendations and suggestions for further research.

\section{References}

Aggarwal, N., \& Gupta, M. (2006). Marketing performance measures : current status in Indian companies. Decision, $33(1), 47-74$.

Aldrich, H. E., \& Waldinger, R. H. (1990). Ethnicity and Entrepreneurship. Annual Review of sociology. http://www.jstor.org/stable/2083265, 16, 111-135. https://doi.org/10.1146/annurev.so.16.080190.000551 
Anetomang, G. G. K. (2009). African Immigrants' Small Business In a Midwestern City in the United States: Constraints and Strategies for Survival. (PhD), Capella University, USA. Retrieved 17/01/2016 from http://search.proquest.com/docview/305160902 (UMI Number: 3366054)

Anderson, R. (2007). Thematic Content Analysis (TCA) Descriptive Presentation of Qualitative Data. Institute of Transpersonal Psychology www.itp.edu www.wellknowingconsulting.org accessed online 16/01/2015.

Baltimore County Public Schools. (2015, 2015). Planning the Methodology - Limitations and Delimitations. $\begin{array}{lllll}\text { Retrieved } \quad \text { March } & \text { 1, 2017, from }\end{array}$ https://www.bcps.org/offices/lis/researchcourse/develop_writing_methodology_limitations.html

Baycan-Levent., T., Gulumser, A. A., Kundak, S., Nijkamp, P., \& Sahin, M. (2006). Diversity and ethnic entrepreneurship (Position paper of research task 4.4). Milan: . Sustainable Development in a Diverse World.

Blalock, H. M. (1967). Toward a theory of minority group relations. New York: Capricorn Books.: Capricorn Books.

Blanche, M., Durrheim, K., \& Painter, D. (2006). Research in practice: Applied methods for the Social Sciences (2nd ed). South Africa: University Cape Town Press Ltd.

Bonacich, E. (1993). The Other Side of Ethnic Entrepreneurship: A Dialogue with Waldinger, Aldrich, Ward and Associates. International migration review, 27, 685-692.

Borjas, G. (1994). The Economics of Immigration. Journal of Economic Literature(32), 1667-1717.

Borjas., G. J. (1986). The self-employment experience of immigrants. The Journal of Human resources., 21, 485-506. https://doi.org/10.2307/145764

Braun, V., \& Clarke, V. (2006). Using thematic analysis in psychology. Qualitative Research in Psychology, 3, 77-101. https://doi.org/10.1191/1478088706qp063oa

Brenner, G. A., Ramangalahy, C., Filion, L., Menzies, T. V., \& Amit, R. T. (2000). Problems Encountered by Chinese Entrepreneurs: a comparative analysis in three major Canadian cities. The 30th European Small Business Seminar, Conference Proceedings, Gent, Belgium, September, 2000.

Bryman, A. (2009). Social Research Methods. New York: Oxford University Press.

Cantillon, R. (1734). Essay on the nature of general commerce. London, UK: Macmillan.

Charles, W. L. H. (2015). International Business: Competing in the Global Market Place. USA: Mc Grwa Hill Education.

Charney, A., \& Libercap, G. D. (2000). Impact of Entrepreneurship Education: Kauffman Centre for Entrepreneurial Leadership.

Chrysostome, E., \& Arcand, S. (2009). Survival of Necessity Immigrant Entrepreneurs: An Exploratory Study. Journal Of Comparative International Management, 12(2), 3-29.

Clark, K., \& Drinkwater, S. (2000). Pushed out or pulled in? Selfemployment among ethnic minorities in England and Wales. Labour Economics(7), 603-628. https://doi.org/10.1016/S0927-5371(00)00015-4

Collins, J. (2003). Australia: cosmopolitan capitalists down under. In Rath, J. \& Kloosterman, R. (2003). immigrant entrepreneurs: venturing abroad in the age of Globalization. Oxford: Berg.

Cromie, S. (2000) Assessing entrepreneurial inclinations: Some approaches and empirical evidence. . European Journal of Work and Organisational Psychology., 9(1), 7-20. https://doi.org/10.1080/135943200398030

Daly, J., Kellehear, A., \& Gliksman, M. (1997). The public health researcher: A methodological approach. Melbourne, Australia:: Oxford University Press.

Dana, L. P. (1995). Entrepreneurship in a Remote Sub-Arctic Community Entrepreneurship Theory and Practice 20(1), 57-72, Fall.

Denscombe., M. (1998). The good research guide for small-scale social reseaerch project. Buckingham, United Kingdom: University Press.

Fairlie, R. W. (2008). Estimating the Contribution of Immigrant Business Owners to the U.S. Economy, U.S. . U.S. Small Business Administration, Office of Advocacy, Washington D.C.

Fairlie., W. R., \& Lofstrom, M. (2013). Immigration and Entrepreneurship. USA: Institute for the Study of Labor. Retrieved from http://ftp.iza.org/dp7669.pdf 
Forbes. (2015). 5 Personality Traits of an Entrepreneur. Retrieved June 25, 2016, 2015, from http://www.forbes.com/sites/johnrampton/2014/04/14/5-personality-traits-of-an-entrepreneur/\#13ada98a22f6

Glancey, K., Greig, M., \& Pettigrew, M. (1998). Entrepreneurial dynamics in small business service firms. International journal of entrepreneurial behaviour \& Research, 4(3), 249-268. https://doi.org/10.1108/13552559810235547

Gomez, D, King, R. Jackson, C. Demographic Profile Report 1: Census 2013 Auckland Usual Residents Snapshot. Auckland Regional Public Health Service. Auckland. July 2014.

Grinnell, R. M., \& Unrau, Y. A. (2005). Social work research and evaluation: quantitative and qualitative approaches. New York:: Oxford University Press.

Hisrich, R. D., \& Peters, M. P. (2002a). Entrepreneurship. New York: McGraw-Hill/Irwin.

Hisrich, R. D., \& Peters, M. P. (2002b). Entrepreneurship. New York, NY: McGraw-Hill/Irwin.

Hofstede, G. (1997). Hofstede, G. (1997), Cultures and Organizations: Software of the Mind. New York, NY: McGraw-Hill.

Holguin, J., Gamboa, E., \& Hoy, F. (2007). Challenges and Opportunities for Hispanic Entrepreneurs in the United States. In Enow Carine Manyi (2010) Immigrant Entrepreneurship. Jonkoping International Business School, Jonkoping University. https://doi.org/10.4337/9781847209962.00020

Kloosterman, R., \& Rath, J. (2003). Immigrant entrepreneurs: venturing abroad in the age of globalization. Oxford: Berg.

Kollinger, P., \& Minniti, M. (2006). Not the lack of trying: American entrepreneurship in black and white. Small Business Economics, 27, 59-79. https://doi.org/10.1007/s11187-006-0019-6

Kolveried, L. (1996). Prediction of Employment Status Choice Intensions. Entrepreneurial theory and practice, Fall, 47-57.

Kristiansen, S., Furuholt, B., \& Wahid, F. (2003). Internet cafe entrepreneurs: pioneers in information dissemination in Indonesia. The International Journal of Entrepreneurship and Innovation, 4(4), 251-263. https://doi.org/10.5367/000000003129574315

Kristiansen, S., \& Indarti, N. (2004). Entrepreneurial Intension among Indonesian and Norwegian Students. Journal of Enterprising Culture, 12(1). https://doi.org/10.1142/S021849580400004X

Lee. (2003). The making of immigrant entrepreneurs: gendered processes of Korean small business ownership. New York: State University of New York.

Lee, \& Peterson, S. J. (2000). Culture, Entrepreneurial Orientation,and Global competitiveness. Journal of World Business., 35, 401-416

Livingstone, K., \& Sarin, T. (2005). The contribution of Asian-owned business to London economy. London: London Chamber. Retrieved from www.london.gov.uk

Lofstrom, M. (2002). Labor market assimilation and the self-employment decision of immigrant entrepreneurs. Journal of Population Economics, 15(1), 83-114. https://doi.org/10.1007/PL00003841

Lumpkin, G. T., \& Dess, G. G. (1996). Clarifying the entrepreneurial orientation construct and linking it to performance. The academy of Management Review, 21, 135-172.

Mamani, B. New Canadian Entrepreneurs: An Unappreciated Contributions to Canadian Prosperity? accessed online March 1, 2017.

Masurel.., E., Nijkamp, P., \& Vindigni. (2004). Breeding places for ethnic entrepreneurs: A comparative marketing approach. Entrepreneurship and Regional Development,, 16(1), 77-86.

Mazzarol, T., Volery, T., Doss, N., \& Thein, V. (1999). Factors influencing small businessstart-ups. International journal of entrepreneurial behaviour \& Research, 5(2), 48-63. https://doi.org/10.1108/13552559910274499

Morgan, G. (2002). Departing Kiwi fuel immigration dilemma. . The National Business Review, 22.

Morris, M. H. (2002). "Revisiting "who" is the entrepreneur. Journal of Developmental Entrepreneurship, 7(1), 5-7.

Morris, M. H., Kuratko, D. F., \& Covin, J. D. (2008). Corporate entrepreneurship and innovation. Mason.: Thomson Higher Education. 
Morrison, M., \& Moir, J. (1998). The role of computer software in the analysis of qualitative data: efficient clerk, research assistant or Trojan horse? Journal of Advanced Nursing, 28(1), 106-116. https://doi.org/10.1046/j.1365-2648.1998.00768.x

Mueller, S. I., \& Thomas, A. S. (2001). Culture and entrepreneurial potential: A nine country study of locus of countrol and innovativeness. Journal of business venturing, 16(1), 51-75. https://doi.org/10.1016/S0883-9026(99)00039-7

Statistics Canada, (2014). http://www.statcan.gc.ca/eng/start accessed online March 2, 2017.

Statistics New Zealand, (2013). 2013 Census. New Zealand: Statistic New Zealand.

Nkrumah., G. (2003). 'Controlling the flow'. Al-Ahram Weekly, 27 June._Al-Ahram Weekly.

Okonta, P., \& Pandya, K. (2007). Entrepreneurial potentials of African-Caribbean in the United Kingdom. . Journal of Small Business \& Enterprise Development, 14(4), 702-718. https://doi.org/10.1108/14626000710832785

Omisakin, O. M., Nakhid, C., Littrell, R., \& Verbitsky, J. (2015). Exploring the Migrant Experience in Small Business Activities in Auckland: A Case Study of African Migrants. Journal of Business Administration Research, 4(2; 2015).

Pinkowski, J. (2009). Challenges and Promise for Immigrant Entrepreneurship in Dublin, report, City of Dublin.

Ram, M., \& Deakins, D. (1996). African-Caribeans in business. Journal of Ethnic and Mgration Studies, 22(1), 67-84. https://doi.org/10.1080/1369183X.1361996.9976522.

Rice, P., \& Ezzy, D. (1999). Qualitative research methods: A health focus. Melbourne, Australia:: Oxford University Press.

Robb, M. A., \& Fairlie, R. W. (2007). Access to Financial Capital among U.S. Businesses: The Case of African American Firms. The ANNALS of the American Academy of Political and Social Science, 613(1), 47-72. https://doi.org/10.1177/0002716207303578

Schmis, A. (2013). Migrant self-employment between precariousness and self-exploitation. www.ephemerajournal.org, 13(1), 53-74.

Simon, J. (1997). Material Welfare and Standard of Living. United State of America: C-SPAN. Retrieved from https://www.youtube.com/watch?v=DoePe89ziXk (June 23, 2010)

Statistics New Zealand. (2016). Unemployment rate. New Zealand: Statistics New Zealand. Retrieved from http://www.stats.govt.nz/browse_for_stats/snapshots-of-nz/nz-progress-indicators/home/economic/unemployme nt-rate.aspx

Volery, T. (2007a). Ethnic entrepreneurship: a theoretical framework. In L. Dana (Ed.), Handbook Of Research On Ethnic Minority Entrepreneurship (pp. 30-41). Cheltenham: Edward Elgar. https://doi.org/10.4337/9781847209962.00009

Volery, T. (2007b). Ethnic entrepreneurship: a theoretical framework. In L. Dana (Ed.), Handbook of research on ethnic minority entrepreneurship. Cheltenham: Edward Elgar. https://doi.org/10.4337/9781847209962.00009

Walrond., C. (2012). Africans - Assimilation and culture Te Ara - the Encyclopedia of New Zealand.

Whitehead, E., Purdy, D., \& Mascarenhas-keyes. (2003). Minority business in England; Report on the annual small business survey 2003 Ethnic boost. Small business sevice, 60/958.

Williams., C. C., Round, J., \& Rodgers, P. (2010). Explaining the off-the-book enterprise culture of Ukraine: Reluctant or willing entrepreneurship? International journal of entrepreneurship small business, 10(2), 165-180. https://doi.org/10.1504/IJESB.2010.033107

Wilson, K. L., \& Portes, A. (1980). "Immigrant Enclaves: An Analysis of The Labour Market Experiences of Cubans in Miami". American Journal of Sociology,, 86, 295-319. https://doi.org/10.1086/227240

Zhou, M. (2004). Revisiting ethnic entrepreneurship: Convergences, controversies, and conceptual advancements. The International Migration Review, 38(3), 1,040-1074. 